\title{
Plant diversity and conservation value of wetlands along a rural-urban gradient
}

\author{
Authors \\ ${ }^{1}$ M.J. du Toit (1) \\ ${ }^{1}$ C. du Preez \\ 'S.S. Cilliers (1)

\section{Affiliations \\ 'Unit for Environmental Sciences and Management, North-West University, Private Bag X6001, Potchefstroom 2520, South Africa.}

\section{Corresponding Author}

Dr M.J. du Toit, 13062638@nwu.ac.za

\section{Dates}

Submitted: 1 October 2019 Accepted: 2 July 2020

Published: 24 February 2021

\section{How to cite this article:}

Du Toit, M.J., Du Preez, C. \& Cilliers S.S., 2021, 'Plant diversity and conservation value of wetlands along a rural-urban gradient', Bothalia 51(1), a4. http://dx.doi. org/10.38201/btha.abc.v51.i1.4
Background: Wetlands are the most threatened ecosystem in South Africa despite the range of ecosystem goods and services they provide. A significant cause of wetland destruction and degradation is a lack of understanding, by planners, policymakers and developers, of their ecological and socio-economic importance.

Objectives: This study assessed the floristic composition and diversity of wetlands in the former Tlokwe Municipal area along a rural-urban gradient.

Methods: Fourteen wetland sites were surveyed along an urbanisation gradient. Vegetation surveys were done in quadrats along transects in each wetland recording the cover-abundance of each species. The data were analysed by using ordinations, similarity percentages, and the adjusted Floristic Quality Assessment Index.

Results: Overall, the proportional species composition of urban and rural wetlands was mainly similar. Trends indicated that the alpha diversity increased with both habitat size and heterogeneity along a rural-urban gradient. In all wetlands, indigenous species were the most abundant, with the highest score in the largest urban wetland. The floristic quality varied widely along the gradient with none of the sites in pristine condition.

Conclusion: The similarity in species composition and floristic quality of the wetlands, as well as the high levels of indigenous species richness, indicated that urban wetlands are worthy of conservation. However, the signs of disturbances and the presence of alien species means that restoration strategies need to be implemented to improve the quality of the wetlands.

Keywords: wetlands, rural-urban gradient, plant diversity, conservation value, floristic quality.

\section{Introduction}

Wetlands play an essential role in biodiversity conservation and in the supply of ecosystem services to humanity (Ramsar Convention Secretariat 2013). They fulfil several ecosystem services such as climate regulation, carbon storage, water reservoirs, runoff containment and flood risk reduction (e.g. Cimon-Morin \& Poulin 2018; McInnes \& Everard 2017). Moreover, they filter pollutants, conserve unique biodiversity, and act as a refuge for species (e.g. Bateganya et al. 2015; Mclnnes \& Everard 2017). Important cultural ecosystem services include increased well-being of residents, eco-tourism, recreation and environmental education (e.g. Pedersen et al. 2019; Ramírez \& Santana 2019).

History showed us that since the Iron Age, extensive drainage of the land took place so that it could be utilised for other purposes such as agriculture and settlements (Everard 1997; Hoeksema 2007). Land drainage happened due to an established idea that wetlands were only sources of disease and danger 
with no intrinsic value in themselves (Purseglove 1989). The Ramsar Convention of 1971 was the primary catalyst for the recognition of the importance of wetlands, and lobbied for global action towards their protection. However, Hettiarachchi et al. (2015) argue that this framework has key weaknesses that contribute to failures in urban wetland governance. Wetlands in urban areas are often regarded as wastelands (Panuccio et al. 2017), and subsequently, urbanisation is recognised as a significant cause of wetland loss (Panuccio et al. 2017). Not only can urban development cause destruction of wetlands, but it often also alters hydrological cycles, increases pollution that transforms wetlands, and influences species composition and species diversity (e.g. Baldwin 2011; Ehrenfeld 2000).

Local perceptions and the direct use of wetlands in urban areas vary. In an urban study in Canada, where residents did not visit local wetlands regularly, they still identified with the aesthetic value of wetlands and its importance as a habitat for biodiversity (Manuel 2003). In Cape Town, residents placed a high value on the provisioning services, mainly grazing for livestock, supplied by a peri-urban wetland and they derived $82 \%$ of their income from this wetland (Lannas \& Turpie 2009). Wetlands were also found to be critical in reducing urban wastewater pollution in areas with malfunctioning or inadequate treatment plants (Bateganya et al. 2015). Moreover, wetland planning is seen as a critical element to be included in urban master plans due to its beneficial functions of flood control, water purification, microclimate regulation, and aesthetic and cultural value (Jia et al. 2011).

Notwithstanding the benefits mentioned above, urban wetlands are also important in urban biodiversity conservation. A study undertaken in Rome, Italy, on the importance of urban wetlands as a habitat for birds, recorded regular observations of species of conservation concern (Panuccio et al. 2017). Construction of urban wetlands in Greensboro, North Carolina, increased bat species richness and diversity (Parker et al. 2018). In addition, in Canada, some urban stormwater ponds had the same plant species, dragonfly and damselfly assemblages as natural ponds, which underlines the importance of urban wetlands to enhance local biodiversity (Perron \& Pick 2020). Moreover, Semlitsch and Bodie (1998) have established that even if small or isolated, wetlands are integral for connectivity and maintaining biodiversity.

In South Africa, Working for Wetlands (2019) estimates that between $35 \%$ and $60 \%$ of the country's wetlands have been destroyed through drainage for crops and pastures, poorly managed burning regimes, overgrazing, disturbances to wetland soils, vegetation clearing as well as industrial and urban development (including mining activities). The latest National Biodiversity Assessment described wetlands as the country's most threatened ecosystem, stating that $88 \%$ of wetland areas are threatened and less than $2 \%$ are well protected (Skowno et al. 2019). Realising the importance of wetlands in South Africa, recent research efforts include the National Wetland Vegetation Database (Sieben et al. 2014) and the updated National Wetland Map 5 (van Deventer et al. 2020). Urban wetlands in South Africa have also seen an increase in research efforts and realisation of their importance, e.g. phytosociological studies of urban wetlands in Potchefstroom (Cilliers et al. 1998) and the Durban municipal area (Roberts 1993), the monetary valuation of provisioning services in a peri-urban wetland in Cape Town (Lannas \& Turpie 2009), amphibians in urban wetlands (Kruger et al. 2015), health effects in fish in wetlands in Soweto (Bengu et al. 2017), wetlands as a habitat for birds (Calder et al. 2015), and the detrimental effects of urban development on wetlands (Govender-Ragubeer et al. 2014). The current study aimed to add to the developing body of knowledge on urban wetlands in South Africa. The primary objective was to assess the floristic composition, quality and diversity of wetlands in the former Tlokwe Municipal area along a rural-urban gradient. The specific research questions were: (1) do urban and rural wetlands differ based on their floristic composition and quality? and (2) are the local urban wetlands worthy of conservation?

\section{Materials and Methods}

\section{Study area}

The study was carried out in the former Tlokwe Municipal area, which now forms a part of the larger, recently amalgamated, JB Marks Local Municipality. The former Tlokwe Municipal area covers $2672 \mathrm{~km}^{2}$, which includes the urban area of Potchefstroom and its rural surroundings (Figure 1) and is located in the North West Province of South Africa. The population estimate of the study area was 179604 in 2018 (JB Marks Local Municipality 2018). Research on the land-use transformation in the study area indicated significant changes in the cover of natural and urban areas over a period of 61 years (Pretorius et al. 2013). This inventory revealed a $23 \%$ increase in urban land coverage and a $68 \%$ increase in cultivated land-uses, decreasing the coverage of natural habitats by $12 \%$ and impacting the coverage of wetlands in the area.

The mean annual rainfall of the study area is $600 \mathrm{~mm}$, falling mainly in the summer months with average temperatures between $0^{\circ} \mathrm{C}$ and $30^{\circ} \mathrm{C}$, and frequent frost in winter (www.weathersa.co.za). The Mooi River flows through Potchefstroom and includes rural upstream and downstream segments with a city segment influenced by decades of urban development. There are various dams situated in the Mooi River system of which the Potchefstroom Dam and Boskop Dam are located 


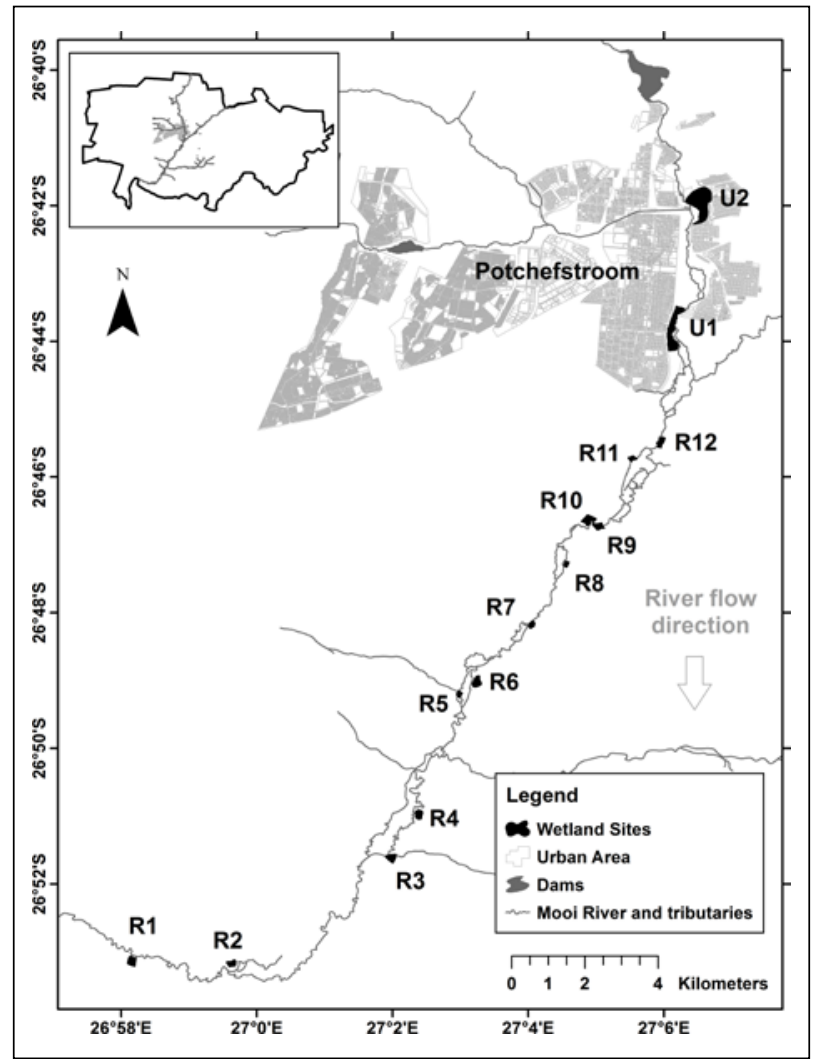

Figure 1. Study area indicating the urban area of Potchefstroom, its rural surroundings and the 14 wetland study sites. Inset map shows the size and location of the urban area and Mooi River within the former Tlokwe Municipal area.

within the municipal area. The water of the Mooi River system is contaminated by agricultural and mining pollutants, of which the impact of mining is of particular concern to the water quality in the system (Barnard et al. 2013). A recent study on phytoplankton assemblages and the measurement of physico-chemical variables in the Mooi River and its tributaries, confirmed that the system was polluted and that the water quality is declining (Koekemoer et al. 2021).

The study area lies within the Grassland Biome on the high central plateau of South Africa and at the confluence of three vegetation types: the Carletonville Dolomite Grassland, the Rand Highveld Grassland, and the Andesite Mountain Bushveld (Mucina et al. 2006). The wetlands in the study area are classified as grass lawn wetland vegetation (Sieben et al. 2016) and temperate grassy wetland vegetation (Sieben et al. 2017).

\section{Site selection}

All possible wetland sites along the Mooi River (excluding its tributaries) within the study area (Figure 1) were identified using satellite imagery. All sites accessible via roads and on private property, where owners granted permission, were visited. Wetlands chosen for this study were those ecosystems defined by the National
Water Act (No. 36 of 1998) (South Africa 1998), as 'land that is transitional between terrestrial and aquatic systems where the water table is usually at or near the surface, or land which is periodically covered with shallow water, and land which, under normal circumstances, supports or would support vegetation typically adapted to live in saturated soils'. To delineate physical wetland boundaries of this study, wetland vegetation was used as an indicator. Fourteen wetland study sites were selected from the city and downstream segments of the Mooi River (Figure 1, Table 1). Approximately $80 \%$ of all the downstream wetlands were included in this study. Table 1 shows the selected wetland sites with their respective sizes and the number of transects surveyed per wetland.

\section{Quantification of the rural-urban gradient}

The rural-urban gradient was objectively quantified using four urbanisation measures namely: edge density, percentage vegetation cover, percentage urban land cover, and density of dwellings as selected by van der Walt et al. (2014) using Hawth's analysis tools version 3.27 (Beyer 2007) and ArcGIS 10 (ESRI 2010). The urbanisation measures were calculated for matrix areas represented by a $500 \mathrm{~m}$ buffer surrounding each selected wetland. Edge density is the sum of the length (m) of all edge segments divided by the area (in hectares) (McGarigal \& Marks 1995). Percentage vegetation and urban land cover were both calculated as the total area covered by each land cover type divided by the total matrix area multiplied by 100 (McGarigal \& Marks 1995). Urban land cover was digitised as all impervious built-up surfaces within the matrix, e.g. roads, buildings. The density of dwellings was calculated by digitised point counts of all the buildings in the matrix divided by the matrix area (McGarigal \& Marks 1995).

Hierarchical, agglomerative cluster analysis in PRIMER 6 software (Clarke \& Gorley 2006) and a subsequent Non-metric Multi-Dimensional scaling (NMDS) ordination indicated two clear groupings in the data (Figure S1 and S2, Supplementary material). Table 1 provides the specific urbanisation measure values for each selected wetland study site. A Pearson $r$ correlation matrix was calculated to see whether one measure could be used as a proxy to represent the rural-urban gradient. All the measures correlated highly with each other, so we chose the percentage urban land cover to represent the gradient as the most intuitive measure (Table S1, Supplementary material). Based on the NMDS and cluster analysis, two sites were classified as urban and 12 as rural. The rural wetlands are all situated in matrix areas that have less than 3\% urban land cover (Table 1), and the two urban sites had a percentage urban land cover ranging between 35 and $45 \%$. 
Table 1. The characteristics of each wetland site and the values of the urbanisation measures used to categorise the sites into urban and rural sites. R, rural sites; R1, furthest away from the city; R12, closest to the city; $U$, urban sites

\begin{tabular}{|c|c|c|c|c|c|c|c|c|}
\hline \multirow[b]{2}{*}{ Site } & \multirow[b]{2}{*}{$\begin{array}{l}\text { Size } \\
\text { (ha) }\end{array}$} & \multirow[b]{2}{*}{$\begin{array}{l}\text { NR of } \\
\text { Transects }\end{array}$} & \multirow[b]{2}{*}{ Landuse } & \multirow[b]{2}{*}{$\begin{array}{l}\text { Management } \\
\text { type }\end{array}$} & \multicolumn{2}{|c|}{ Urbanisation measures } & \multirow[b]{2}{*}{$\begin{array}{l}\text { Percentage } \\
\text { vegetation } \\
\text { cover }\end{array}$} & \multirow[b]{2}{*}{$\begin{array}{l}\text { Density of } \\
\text { dwellings }\end{array}$} \\
\hline & & & & & $\begin{array}{l}\text { Percentage } \\
\text { urban land } \\
\text { cover }\end{array}$ & $\begin{array}{l}\text { Edge } \\
\text { density }\end{array}$ & & \\
\hline $\mathrm{R} 1$ & 3.79 & 9 & Rural agriculture & Grazing & 2.43 & 263.765 & 87.93 & 0.256 \\
\hline $\mathrm{R} 2$ & 2.58 & 5 & Rural agriculture & Grazing & 1.25 & 293.14 & 87.59 & 0.107 \\
\hline R3 & 3.41 & 5 & Rural agriculture & Grazing & 2.75 & 188.98 & 90.57 & 0.121 \\
\hline $\mathrm{R} 4$ & 3.21 & 4 & Rural agriculture & Grazing & 0.04 & 218.076 & 99.62 & 0.018 \\
\hline R5 & 1.44 & 3 & Rural agriculture & Grazing & 0.03 & 130.043 & 96.72 & 0 \\
\hline R6 & 4.24 & 4 & Rural agriculture & Grazing & 0.51 & 177.39 & 94.92 & 0 \\
\hline R7 & 1.76 & 4 & Rural agriculture & Grazing & 2.46 & 217.995 & 96.29 & 0.201 \\
\hline R8 & 1.14 & 3 & Rural agriculture & Grazing & 1.51 & 230.765 & 93.83 & 0.05 \\
\hline R9 & 2.95 & 6 & Rural agriculture & Grazing & 1.63 & 218.115 & 96.22 & 0.051 \\
\hline R10 & 4.79 & 10 & Rural agriculture & Grazing & 0.72 & 201.93 & 97.5 & 0 \\
\hline $\mathrm{R} 11$ & 1.47 & 3 & Rural agriculture & Grazing & 1.97 & 205.553 & 95.5 & 0.086 \\
\hline $\mathrm{R} 12$ & 2.85 & 6 & Rural agriculture & Grazing & 1.98 & 266.72 & 93.53 & 0.094 \\
\hline U1 & 17.01 & 30 & Urban & $\begin{array}{l}\text { Grazing and Bird } \\
\text { Sanctuary }\end{array}$ & 35.9 & 397.045 & 63.79 & 3.66 \\
\hline U2 & 31.58 & 38 & Urban & $\begin{array}{l}\text { Grazing and } \\
\text { Recreational } \\
\text { activities }\end{array}$ & 43.77 & 477.458 & 55.34 & 3.661 \\
\hline
\end{tabular}

\section{Vegetation surveys}

Vegetation surveys were conducted from January to March 2014, during the flowering season of most plants. Plant species composition and abundance within the wetlands were determined by laying $100 \mathrm{~m}$ line transects across each wetland (Ruto et al. 2012). Transects were aligned along the longest axis of each wetland. Where sites were wide enough, adjacent transects were sampled parallel to one another, $20 \mathrm{~m}$ apart. The number of transects per selected wetland was determined by the size of the wetland under observation. A minimum of three transects were done per wetland (since the smallest wetlands could only fit three transects with $20 \mathrm{~m}$ between each transect). The largest wetland (U2) had 38 transects (Table 1). The presence and estimated percentage crown cover of each plant species were determined in a $1 \mathrm{~m}^{2}$ quadrant placed at $10 \mathrm{~m}$ intervals along the $100 \mathrm{~m}$ transects (Ruto et al. 2012) situated in homogenous areas of each wetland site. A total of 130 transects (1 254 quadrants, not all transects had 10 sample plots due to open water areas) were sampled in the 14 wetland sites.

The soft traits used in this study included the origin of each species (indigenous/alien), life history (annual/perennial), growth form (tree, shrub, forb, graminoid and geophyte) and wetland indicator status. The wetland indicator status divides plants into categories based on their expected frequency of occurrence in wetlands namely obligate wetland (>99\%), facultative wetland (67-99\%), facultative (34-66\%), facultative upland (1$33 \%)$ and upland $(<1 \%)$ (Tiner 2006).

\section{Data analysis}

The floristic composition of each of the wetlands was compared using NMDS. The ordination was performed using the Primer 6 software (Clarke \& Gorley 2006). The average percentage cover of species per transect was used as input for the ordination. The sample data was first square root transformed to allow a greater contribution from the rare species, and then sites were compared using the Bray-Curtis dissimilarity coefficient. To determine the percentage dissimilarity between urban and rural sites based on the cover-abundance data, a similarity percentages (SIMPER) analysis was done in Primer 6. This analysis compared sites based on respective species composition and also indicates which species account for dissimilarities between sites.

The Wetland Index Value or WIV for each wetland site surveyed (i.e., community weighted mean) were calculated using the abundance of plant species and their 
ecological index value based on their wetland indicator status (Carter et al. 1988). The WIV provides a useful way of interpreting the status of wetlands based on their vegetation composition and is based primarily on the relevant species' wetland indicator status (Cowden et al. 2014). The values represent a wetness gradient with values less than 2.5 indicating a true wetland and values above 3.6 a non-wetland area (Carter et al. 1988)

Data on the abundance of plant species and their classification status were used to determine the adjusted Floristic Quality Assessment Index (adjFQAI), as defined by Miller and Wardrop (2006). The adjFQAI addresses the problem of sensitivity to species richness and the contribution of non-native species (Miller \& Wardrop 2006). The adjFQAI is an evaluation procedure that indicates the quality of the wetland habitat based on the relative abundance of indigenous, weedy, pioneer or alien invasive species within each surveyed site. Moreover, the adjFQAI calculates the percentage of the maximum value attainable by the site if all the species present were low tolerance indigenous species indicative of pristine wetland communities (Miller \& Wardrop 2006). Species were assigned a 'coefficient of conservatism' that is 'a subjective rating indicating a species' preference for non-degraded natural communities' (Tiner 1999). Within the selected wetland sampling sites, each plant species was allocated a specific coefficient of 0 to 10 based on its conservation value relative to other native species in the surrounding area. Values ranged between alien species (0) and indigenous species with very low tolerances, to disturbance and high fidelity to habitat integrity (10) (Miller \& Wardrop 2006). The allocation of the coefficient was based on available literature (Retief \& Herman 1997; Van Ginkel et al. 2011).

\section{Results}

\section{Plant species composition and diversity}

The total number of species recorded in the wetlands along the rural-urban gradient was 102 (for the complete species lists and the list of invasive alien species recorded in the sites refer to Tables S2 and S3 in the supplementary material). Rural sites had a slightly higher gamma diversity than urban sites, but proportionately their overall species composition, diversity, origin, life history and wetland indicator status types were mostly similar (Table 2).

The analysis of the similarity between urban and rural sites in the current study indicated that the two urban sites were $67 \%$ similar, with the 12 rural sites displaying only $45 \%$ similarity. The average dissimilarity between urban and rural sites was $62 \%$. Table 3 indicates that $22 \%$ of the dissimilarity between urban and rural sites in this study was due to the difference in abundance

Table 2. Plant species diversity, traits and wetland indicators of urban and rural land-use sites. The species richness (SR) and percentage contribution (\%) of each category are listed

\begin{tabular}{|c|c|c|c|c|c|}
\hline & & Urban & & Rural & \\
\hline Category & Trait & SR & $\%$ & SR & $\%$ \\
\hline Gamma diversity & Total per land use type & 69 & - & 78 & - \\
\hline \multirow[t]{2}{*}{ Origin } & Indigenous & 47 & 68.1 & 56 & 71.8 \\
\hline & Alien & 22 & 31.9 & 22 & 28.2 \\
\hline \multirow[t]{5}{*}{ Growth Form } & Geophyte & 1 & 1.4 & 2 & 2.6 \\
\hline & Graminoid & 15 & 21.7 & 21 & 26.9 \\
\hline & Forb & 49 & 71 & 53 & 67.9 \\
\hline & Shrub & 1 & 1.4 & 1 & 1.3 \\
\hline & Tree & 3 & 4.3 & 1 & 1.3 \\
\hline \multirow[t]{2}{*}{ Life history } & Annual & 18 & 26.1 & 23 & 29.5 \\
\hline & Perennial & 51 & 73.9 & 55 & 70.5 \\
\hline \multirow[t]{5}{*}{ Wetland indicator species } & Obligate wetland & 29 & 42 & 27 & 34.6 \\
\hline & Facultative wetland & 16 & 23.2 & 19 & 24.4 \\
\hline & Facultative & 12 & 17.4 & 18 & 23.1 \\
\hline & Facultative upland & 9 & 13 & 14 & 17.9 \\
\hline & Upland & 3 & 4.3 & 0 & 0 \\
\hline
\end{tabular}


of four species. Of the four species, Carex glomerabilis Krecz., Paspalum dilatatum Poir. and Typha capensis (Rohrb.) N.E.Br. almost exclusively occurred only in the two urban sites, whereas Cyperus longus L. had higher abundances in the urban sites than in the rural sites.

Table 3. SIMPER analysis indicating the species which contributed to $50 \%$ of the dissimilarity between urban and rural sites. Listed are the average abundance, percentage contribution, and the cumulative percentage contribution of each species. The asterisk indicates an alien species

\begin{tabular}{|c|c|c|c|c|}
\hline 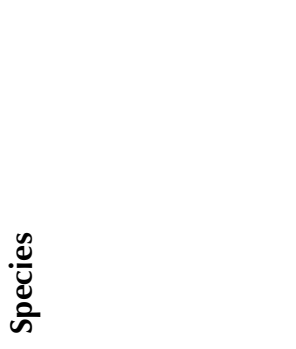 & 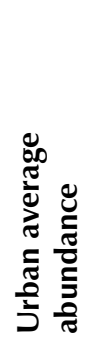 & 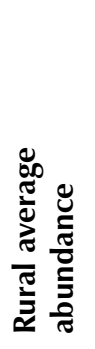 & 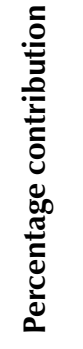 & 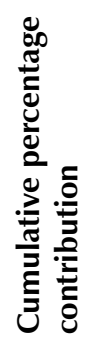 \\
\hline Carex glomerabilis & 2.97 & 0.17 & 6.66 & 6.66 \\
\hline Paspalum dilatatum* & 3.11 & 0.65 & 5.85 & 12.51 \\
\hline Cyperus longus & 3.95 & 1.81 & 5.17 & 17.68 \\
\hline Typha capensis & 2.01 & 0.12 & 4.46 & 22.14 \\
\hline Cyperus laevigatus & 2.11 & 1.08 & 4.18 & 26.32 \\
\hline Cyperus fastigiatus & 1.29 & 2.05 & 4.08 & 30.4 \\
\hline Paspalum distichum & 2.05 & 2.03 & 3.83 & 34.23 \\
\hline Leersia hexandra & 3.16 & 1.88 & 3.5 & 37.73 \\
\hline Echinochloa holubii & 0.11 & 1.6 & 3.47 & 41.2 \\
\hline Cynodon dactylon & 1.78 & 0.35 & 3.41 & 44.62 \\
\hline Falkia oblonga & 2.88 & 1.82 & 3.34 & 47.95 \\
\hline Berula erecta & 1.51 & 0.13 & 3.24 & 51.19 \\
\hline
\end{tabular}

The first three species were also listed as historically occurring in the wetlands of the region (Louw 1951).

Overall, the ordination of average cover-abundance per transect per site indicated no distinct differences between urban and rural sites (Figure 2). However, groupings within the sample sites are visible, indicating differences in species composition. The closer similarity of some $\mathrm{U} 1$ transects with the rural transects, indicated the transitional nature of this site along the gradient. The reason for this pattern might be the location of this site on the periphery of the urban area.

Due to the small number of wetland sites and the absence of sites representing the full range of the gradient (rural sites were limited to 0-3\% urban land cover, while urban sites had $35-45 \%$ urban land cover), we did not do any statistical analyses on correlations between sites along the gradient. However, the influence of urbanisation on wetlands was explored by arranging the sites along the rural-urban gradient from the site with the lowest percentage urban land cover to one with the highest percentage urban land cover in all the following graphs.

The alpha diversity graph indicates that there was an overall trend of increased species richness along the urbanisation gradient (Figure 3a). The difference in sizes of the various sites partially explains this phenomenon, especially with regards to the urban wetlands (Figure 3c). The same trend is not apparent in the average species richness per transect per site (Figure 3b). Beta diversity was calculated as (i) the average beta diversity per site between the 12 rural sites; (ii) the average beta diversity between the two urban sites and all the rural sites; and (iii) the beta diversity between the two urban sites (Figure 4a). The graph indicates a visible, increasing trend of more unique species recorded as urbanisation

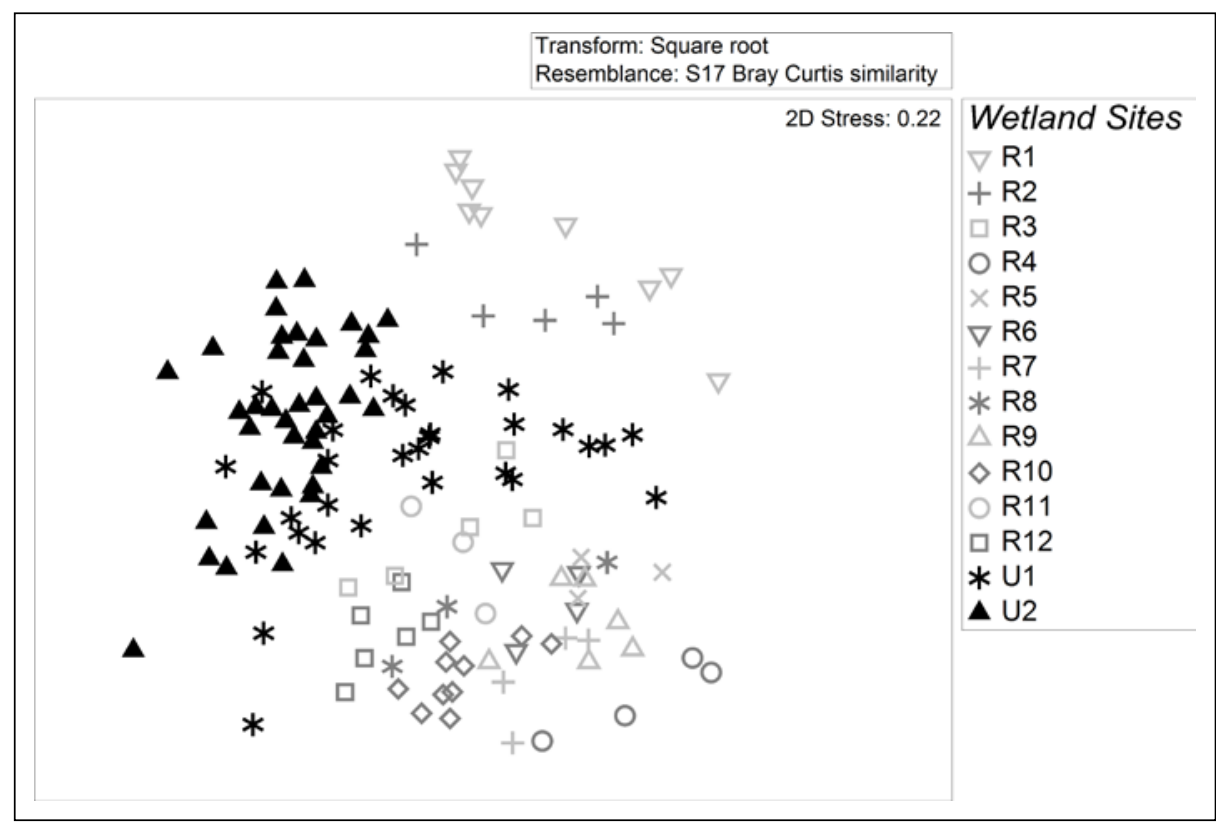

Figure 2. NMDS ordination for the average cover-abundance per transect per site of all species. 


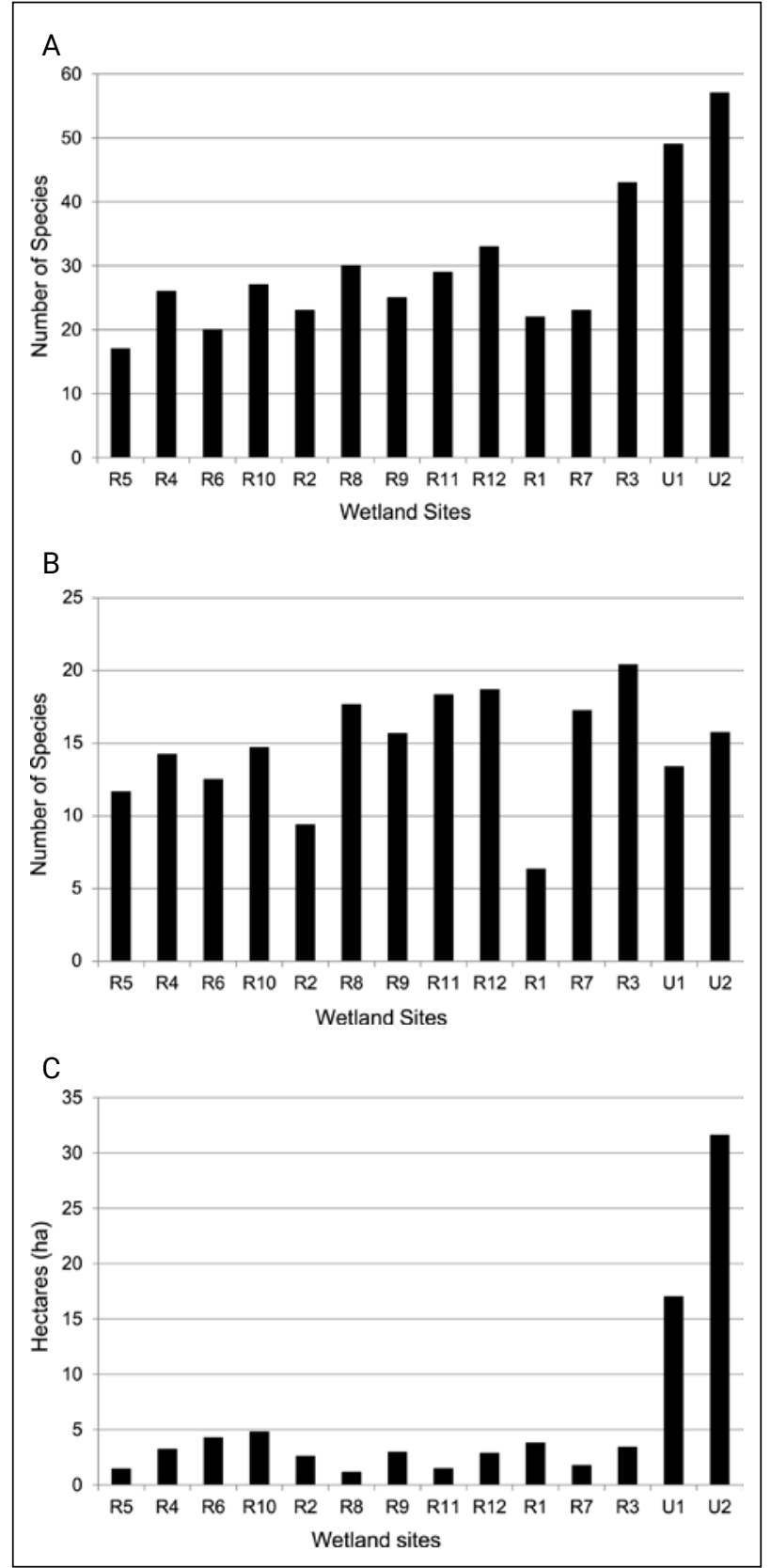

Figure 3. A, Total number of species per wetland site (alpha diversity); $\mathrm{B}$, the average species richness per transect for each site; C, the size of each wetland; arranged along a gradient of increasing percentage urban landcover.

increases, linked to both an increase in size and habitat heterogeneity (Kallimanis et al. 2008). The graph also indicates that the two urban wetlands shared more species than having unique species, which was reversed in the rural wetlands. This observation reflects the results of the SIMPER analysis reported earlier, which indicated that urban sites were more similar than rural sites. However, analysis of the similarity of the transects of each respective site indicated a trend of decreased similarity of the sites as the percentage urban land cover increased (Figure $4 b$ ). The ordination also shows that the rural sites were not closely associated with each other (Figure 2). The high alpha diversity of urban sites is supported by

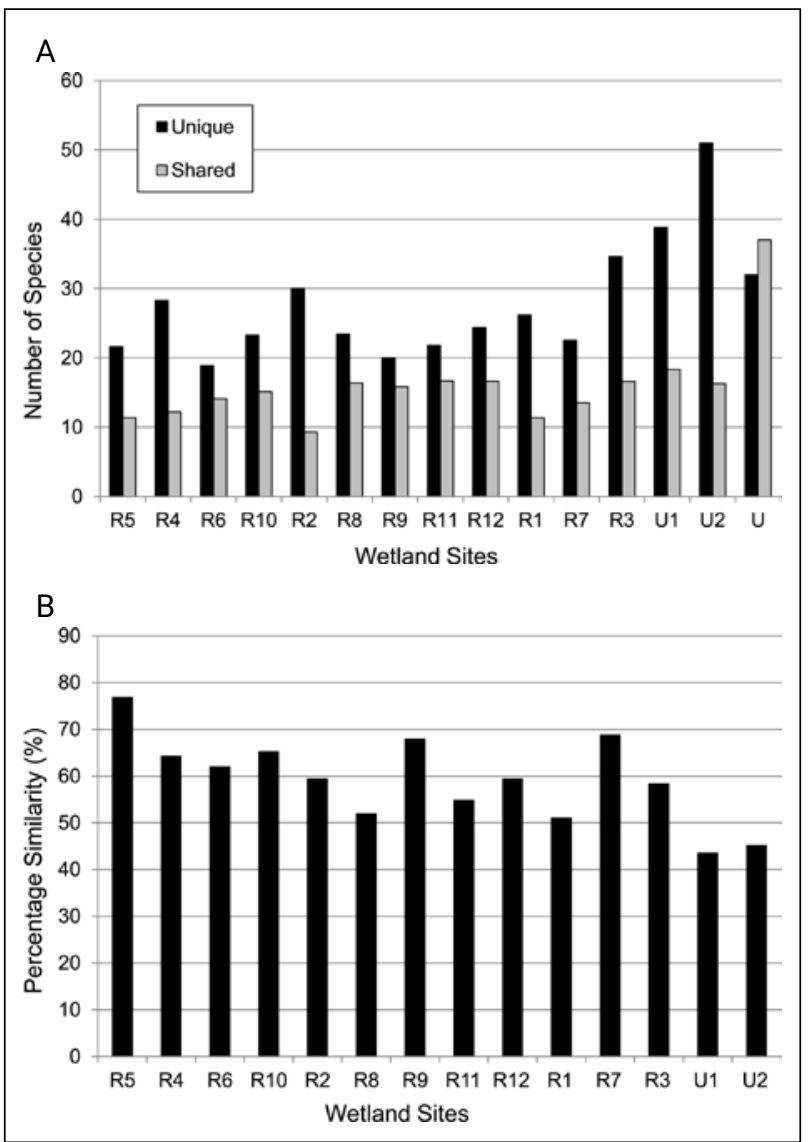

Figure 4. A, Beta diversity between sites (calculated as the average between all the rural sites (R1-R12), the average between the two urban sites and all the rural sites ( $\mathrm{U} 1$ and $\mathrm{U} 2$ ), and between the two urban sites (U)); B, the SIMPER analysis results of the average similarity of the transects in each wetland site; arranged along a gradient of increasing percentage urban landcover.

the low percentage of similarity of its transects within the sites, indicating heterogeneity (Figure 4b).

\section{Functional diversity}

The wetland index values indicated that all the sites are true wetlands with values well below 2.5 (Cowden et al. 2014) and were, therefore, comparable (Figure 5a). The overall cover-abundance of vegetation in each site varied with no apparent link to a trend along the gradient (Figure 5b). The percentage composition of the specific growth forms, and the wetland indicator types, showed no marked differences along the gradient (Figure 5c 

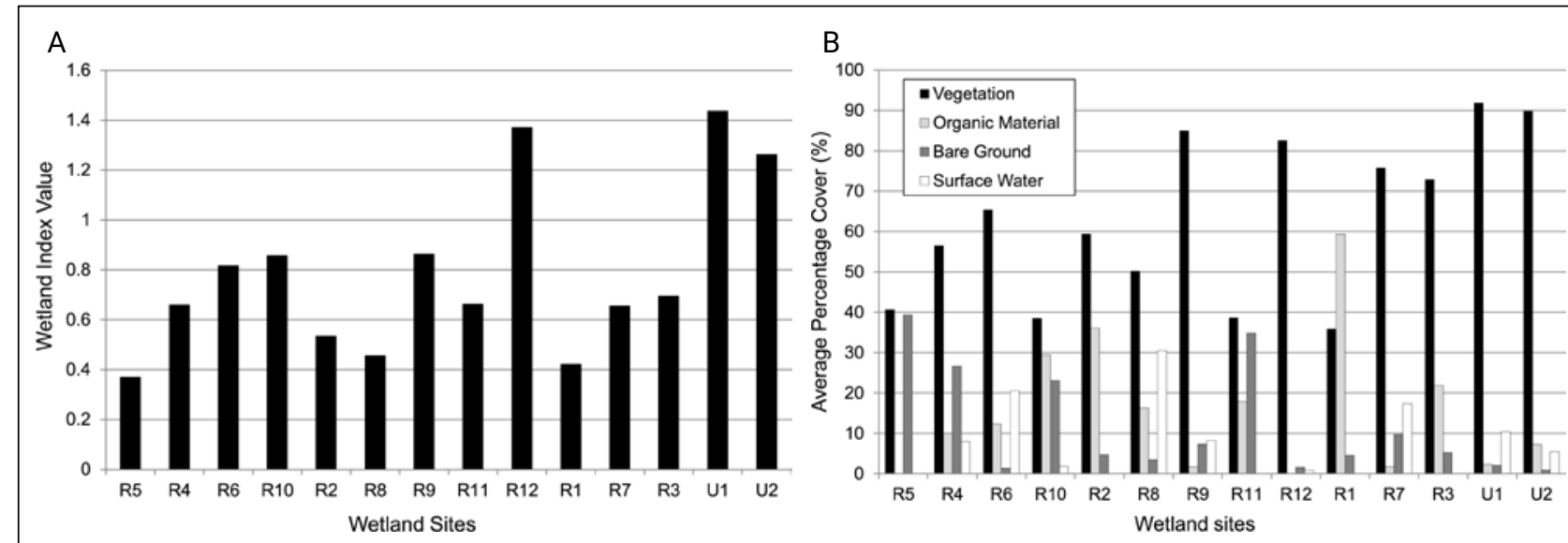

C

$\mathrm{D}$
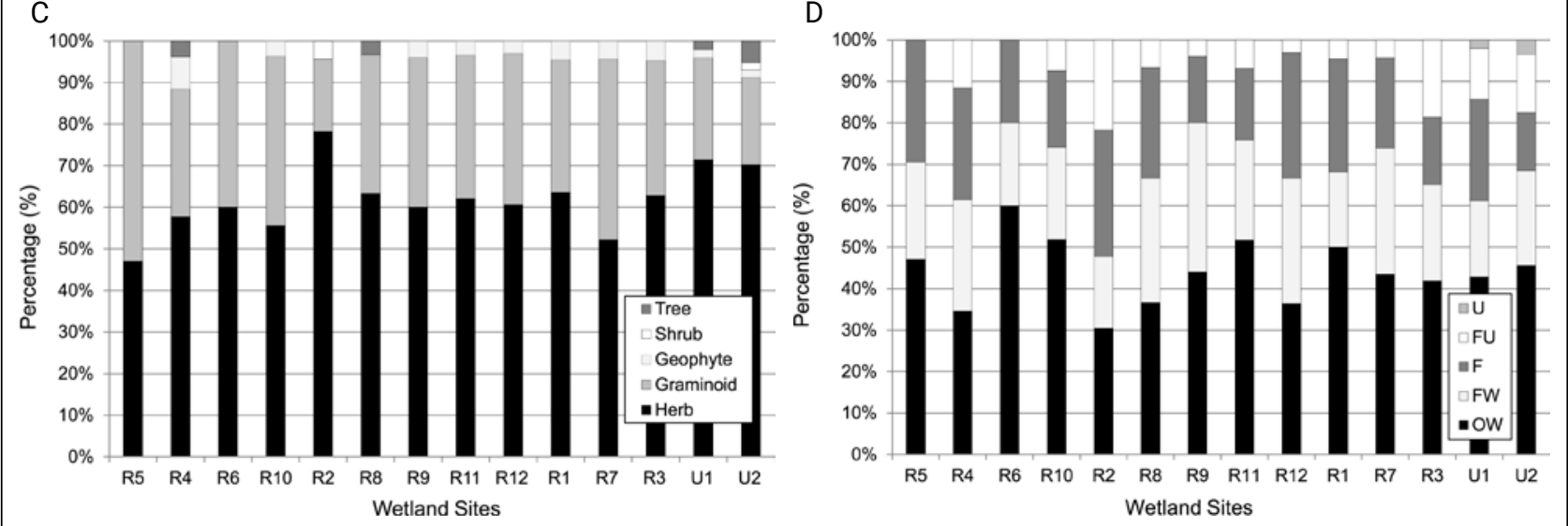

Figure 5. A, Wetland index values (WIV) of each site; B, the average site cover descriptions; $\mathrm{C}$, the percentage average growth form distribution at each site; $\mathrm{D}$, the average functional diversity per site (upland (U), facultative upland (FU), facultative (F), facultative wetland (FW), obligate wetland (OB)); arranged along a gradient of increasing urban landcover.

and d). The higher wetland indicator values of the urban wetlands indicated the presence of more facultative upland and upland species in comparison to the other wetlands (Figure $5 \mathrm{~d}$ ). The trends of the vegetation coverabundance graph and the wetland indicator graphs are very similar, indicating that the higher cover-abundance of vegetation might signify drier conditions.

\section{Quality}

The origin of wetland species indicates the quality of the habitats. In all sites, the indigenous species dominated proportionately based on the total average cover of species per site (Figure 6a and c). A visible trend of higher indigenous and alien species richness with increased urban land cover was also observed. The urban sites, specifically, had a much higher alien species richness (Figure $6 \mathrm{~b}$ ). The cover-abundance of alien species showed no visible trend along the gradient. The greater the difference between the number of indigenous and alien species, the higher was the adjusted floristic quality assessment index (adjFQAI) (Figure 6d). Sites with the highest proportion of indigenous species (Figure 6a) had the highest adjFQAI values. There was no visible trend of any influence of position along the gradient on the quality of the sites.

\section{Discussion}

The effect of the urbanisation gradient was only visible in the trends of overall species richness and both indigenous and alien species richness. We acknowledge that the larger size of the urban wetlands affected increased species richness (Kallimanis et al. 2008). However, the high species richness of the most urbanised rural site had no relation to its size. Moreover, this site (R3) had a higher indigenous species richness than the smaller of the two urban wetlands (U1). Kallimanis et al. (2008) showed that higher species richness is also linked to increased habitat diversity. The only other phenomenon that showed a possible linkage to the amount of urban land cover was the analysis of the similarity of the transects within each site, indicating a downward trend with an increased heterogeneity along the gradient. There was no link between the wetland indicator values and the percentage of urban land cover in this study, indicating that site-specific factors were involved. This observation was also true for the quality of the wetlands indicated by the adjusted floristic quality assessment index.

Bare ground and high organic material cover seemed to explain the low species richness of some rural sites. A dense litter layer is a general constraint to the species 

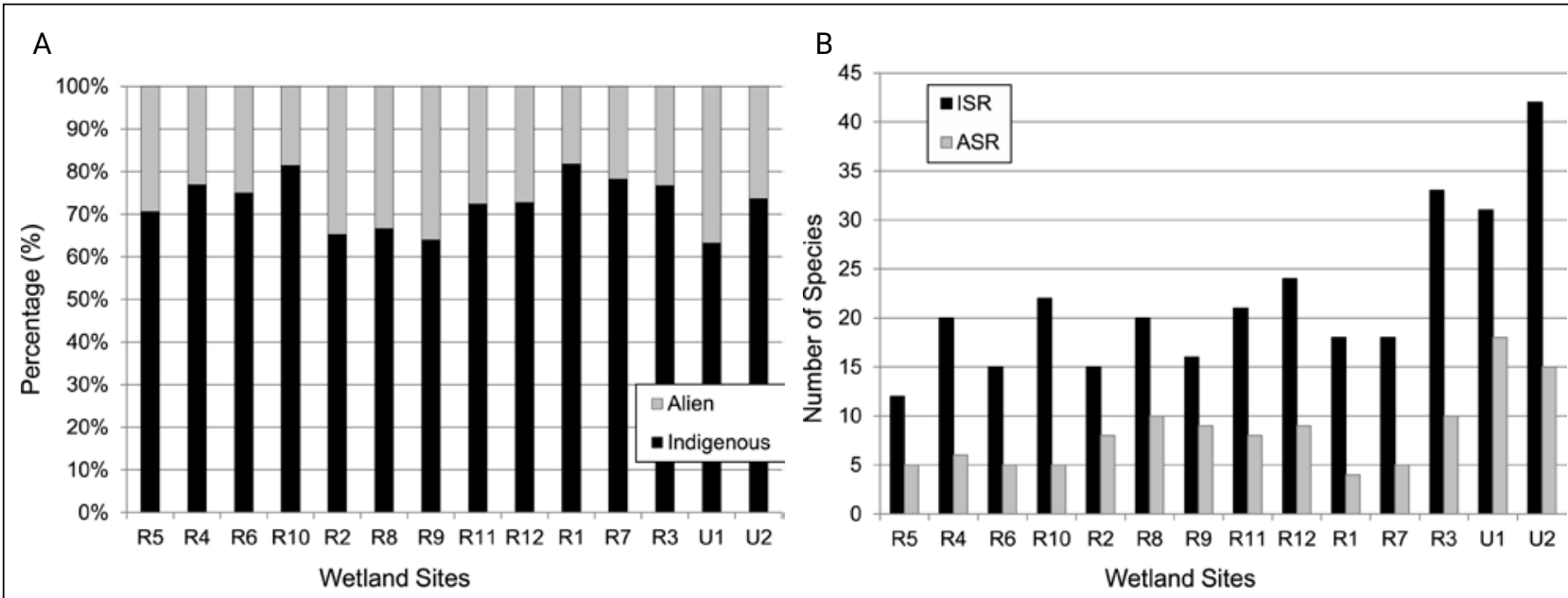

C
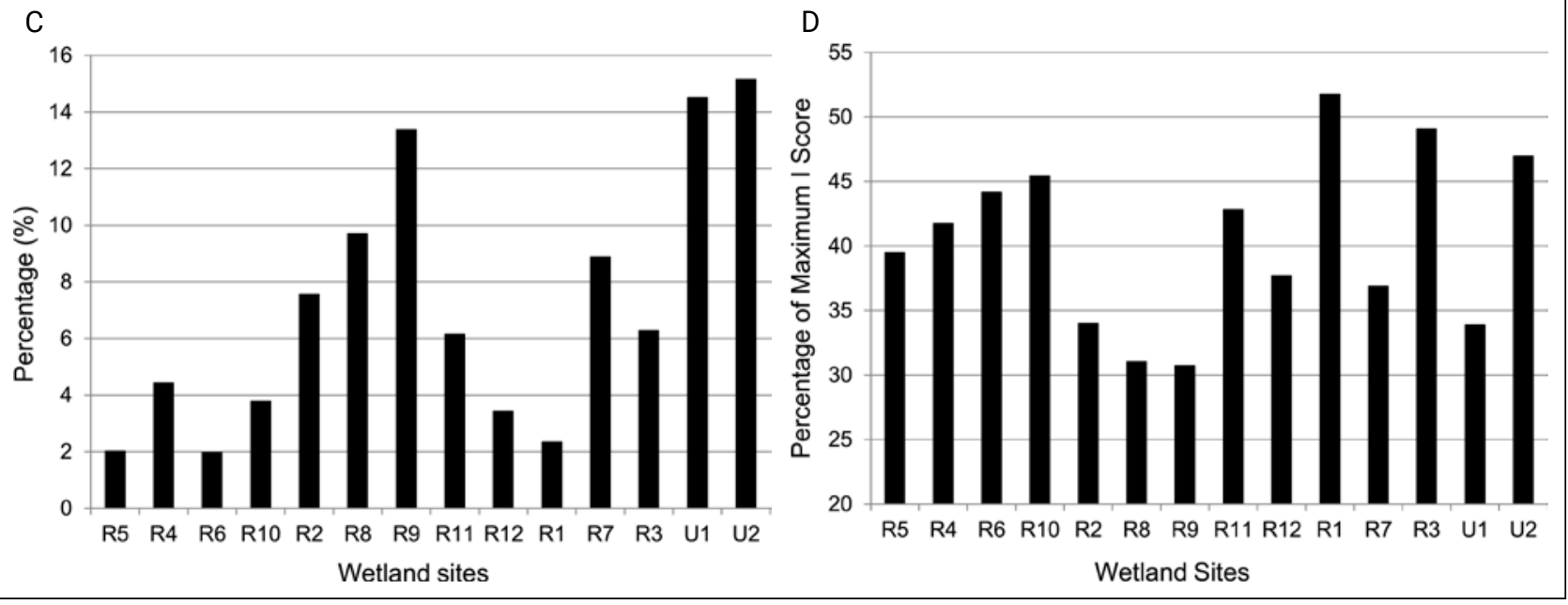

Figure 6. A, Percentage distribution of alien and indigenous species per site; B, the indigenous (ISR) and alien (ASR) species richness per site; C, the percentage of the total average cover of all alien species per site; D, the associated adjusted Floristic Quality Assessment Index values (adjFQAI) of each site; arranged along a gradient of increasing percentage urban landcover.

richness of wetlands (Doherty \& Zedler 2014), where the high cover percentage of organic material in some rural wetlands could be one of the reasons why they have a lower number of species. According to Cilliers et al. (1998), a large number of plant communities occurred in these urban wetlands suggesting high heterogeneity. Moreover, both urban wetlands serve as urban stormwater discharges with channels dug into the sites. These channels increase the influx of pollution and alien plant propagules into the wetlands. The overabundance of seed sources in urban areas could also increase species richness in these sites. However, the overall high similarity analysis of the two urban sites $(67 \%)$ in comparison to rural sites might support the findings of Ding et al. (2019) in research done on 35 cities in China. They found that comparisons of floristic similarity of aquatic macrophytes were much higher in the urban communities than in the rural communities, suggesting biotic homogenisation. Furthermore, they state the high proportion of shared common species as a possible reason (Ding et al. 2019).

Although the aim of this study was neither to classify wetland vegetation nor to compare the species composition and abundance of the studied wetlands with previous studies of urban (Cilliers et al. 1998) and rural wetlands (Louw 1951), the results do suggest some changes to these wetlands over the years. Firstly, the Cynodon dactylon (L.) Pers. invasive community had probably increased in area as both urban wetlands still have continuous grazing and trampling pressures by cattle and horses. Weedy species, such as C. dactylon, are well adapted to these disturbed conditions as they can replace damaged tissues quickly, and due to their rhizomatous nature, they are good colonisers (Cilliers et al. 1998; Sieben et al. 2014). Secondly, the high abundance of Phragmites australis (Cav.) Steud. and $T$. capensis in certain areas of the urban wetlands could indicate an increase of cover in the two communities dominated by these species. This dominance was probably due to the urban stormwater runoff outlets into the wetlands, favouring these species which are well adapted to waterlogged conditions. These species are also well adapted to eutrophication (Sieben et al. 2014). Although urbanisation has influenced wetlands in Potchefstroom, it is difficult to determine the extent thereof as no detailed studies were done of reference 
conditions. Louw (1951) has already indicated the effect of disturbances, such as the artificial drainage of the wetland areas due to irrigation. A large number of indigenous wetland species, such as the free-floating hydrophytes and many of the marshland species described by Louw (1951), were not encountered in the rural and urban wetlands of the current study. The reed swamp communities dominated by $P$. australis and T. capensis were also quite extensive in the rural wetlands described by Louw (1951), but an invasion by C. dactylon was not mentioned at all.

Wondie (2018) found in a study in Ethiopia, that although the impaired urban and agricultural wetlands had a higher plant species diversity than the natural wetlands, the majority of these plant species were alien weeds and upland species, outcompeting the native species, which are ecologically and socio-economically important. They described the main reasons to be direct and indirect anthropogenic activities, including waste discharges through streams and ditches in towns. Wastewater management is a huge challenge in cities in sub-Saharan Africa, and Bateganya et al. (2015) explained that urban wetlands are considered as natural features to aid conventional municipal wastewater treatment plants that are ineffective due to overloading and poor maintenance. Other studies have also indicated that urban wetlands usually have a higher alien species richness than rural wetlands (Albert \& Minc 2004; Dallimer et al. 2012; Dolan et al. 2011). The higher alien species richness was also true for the two urban wetlands in this study. However, the most urbanised wetland had the highest indigenous species richness of any of the sites. The high species richness was certainly linked to the size of the wetland. The results of the adjusted floristic quality assessment index indicated that none of the wetlands is in a pristine condition (Miller \& Wardrop 2006). However, in all of the sites, indigenous species constitute more than $60 \%$ of the species richness and more than $85 \%$ of the cover-abundance. Therefore, if correct remediation and ecological restoration techniques were to be applied, these wetlands can be restored (Baldwin 2011) to provide a variety of ecosystem services (Cilliers et al. 2013). Urban wetlands are often perceived as of poor quality and highly disturbed (Panuccio et al. 2017), but in the current study, the largest urban wetland also had the highest indigenous species richness with the third-highest floristic quality value. The high indigenous species richness means that in this study, urban wetlands are vital for the conservation of local biodiversity and highlights the value that urban wetlands have in enhancing and supporting biodiversity (Baldwin 2011). Wetland plants are adapted to long-distance wind and water dispersal (Soomers et al. 2013). Therefore, adequately connected sites can harbour high species richness despite fragmentation pressures (Soomers et al. 2013). However,
Cimon-Morin and Poulin (2018) remind us that it is a challenge to conserve small urban wetlands as decision-makers often do not recognise their importance both in terms of ecosystem services and biodiversity within the larger wetland system.

The limitations of this study included a lack of access to all potential sites and sampling only within the former Tlokwe Municipal area. Increasing sampling to upstream and other nearby urban wetlands, and incorporating the landscape history of the sites, would clarify identified trends and provide a better understanding of the local drivers of wetland diversity in the area.

\section{Conclusions}

This small, localised study identified possible trends due to the impact of urbanisation on wetland communities along a rural-urban gradient. However, the urbanisation gradient did not correlate with wetland indicator values or the floristic quality of the sites indicating that other drivers were responsible for the observed patterns. Nevertheless, our study highlighted the potential importance of urban wetlands for the conservation of biodiversity. In our study, the much larger urban wetlands had the highest and third-highest indigenous species richness as well as a higher floristic quality than most of the rural sites. However, the signs of disturbances and the presence of alien species means that restoration strategies need to be implemented to improve the quality of the wetlands. Notwithstanding their essential role in stormwater discharge already implemented in the municipality, urban wetlands have multiple other ecosystem service benefits that in combination with their high biodiversity, make them essential to conserve.

\section{Authors' contributions}

MJDT assisted with fieldwork, conducted data analyses and wrote half of the manuscript; CDP did the study as a masters' project, she did the field work and wrote parts of the current manuscript; SSC planned and coordinated the study, assisted with fieldwork and wrote half of the manuscript.

\section{Disclaimer}

The views expressed in the submitted article are our own and not an official position of the institution or funder.

\section{Source(s) of Support}

National Research Foundation. 


\section{References}

Albert, D. \& Minc, L., 2004, 'Plants as regional indicators of Great Lakes coastal wetland health', Aquatic Ecosystem Health \& Management, 7(2), 233-247. https://doi. org/10.1080/14634980490461588

Baldwin, A., 2011, 'Plant communities of urban wetlands: patterns and controlling processes', in J. Niemelä (Ed.) Urban Ecology: Patterns, Processes, and Applications. New York: Oxford University Press, pp. 77-84. DOI:10.1093/ acprof:oso/9780199563562.003.0010

Barnard, S., Venter, A., \& Van Ginkel, C., 2013, 'Overview of the influences of mining-related pollution on the water quality of the Mooi River system's reservoirs, using basic statistical analyses and self organised mapping', Water $S A$, 39(5), 655-662. DOI: 10.4314/wsa.v39i5.10

Bateganya, N.L., Nakalanzi, D., Babu, M., \& Hein, T., 2015, 'Buffering municipal wastewater pollution using urban wetlands in sub-Saharan Africa: a case of Masaka municipality, Uganda', Environmental Technology, 36(17), 21492160. https://doi.org/10.1080/09593330.2015.1023363

Bengu, T.S., du Plessis, J., Modley, L.S., \& van Dyk, J.C., 2017, 'Health effects in fish from the polluted Orlando Dam and Klipspruit wetland system, Soweto, South Africa', African Journal of Aquatic Science, 42(2), 131-141. https://doi.org $/ 10.2989 / 16085914.2017 .1347083$

Beyer, H.L., 2007, Hawth's Analysis Tools Version 3.27, Retrieved from http://www.spatialecology.com/htools/download.php

Calder, J.-L., Cumming, G.S., Maciejewski, K., \& Oschadleus, H.D., 2015, 'Urban land use does not limit weaver bird movements between wetlands in Cape Town, South Africa', Biological Conservation, 187, 230-239. https://doi. org/10.1016/j.biocon.2015.04.021

Carter, V., Garrett, M.K., \& Gammon, P.T., 1988, 'Wetland Boundary Determination In The Great Dismal Swamp Using Weighted Averages ${ }^{1}$, JAWRA Journal of the American Water Resources Association, 24(2), 297-306. https://doi. org/10.1111/j.1752-1688.1988.tb02987.x

Cilliers, S., Cilliers, J., Lubbe, R., \& Siebert, S., 2013, 'Ecosystem services of urban green spaces in African countries - perspectives and challenges', Urban Ecosystems, 16(4), 681-702, https://doi.org/10.1007/s11252-012-0254-3

Cilliers, S.S., Schoeman, L.L., \& Bredenkamp, G.J., 1998, 'Wetland plant communities in the Potchefstroom Municipal area, North-West, South Africa', Bothalia, 28(2), 213-229, https://doi.org/10.4102/abc.v28i2.642

Cimon-Morin, J., \& Poulin, M., 2018, 'Setting conservation priorities in cities: approaches, targets and planning units adapted to wetland biodiversity and ecosystem services', Landscape Ecology, 33(11), 1975-1995. https://doi. org/10.1007/s10980-018-0707-z

Clarke, K.R., \& Gorley, R.N., 2006, 'PRIMER v6: User Manual/ Tutorial', Plymouth: PRIMER-E Ltd.

Cowden, C., Kotze, D.C., Ellery, W.N., \& Sieben, E.J.J., 2014, 'Assessment of the long-term response to rehabilitation of two wetlands in KwaZulu-Natal, South Africa', African Journal of Aquatic Science, 39(3), 237-247, https://doi.org $/ 10.2989 / 16085914.2014 .954518$

Dallimer, M., Rouquette, J.R., Skinner, A.M.J., Armsworth, P.R., Maltby, L.M., Warren, P.H., \& Gaston, K.J., 2012,
'Contrasting patterns in species richness of birds, butterflies and plants along riparian corridors in an urban landscape', Diversity and Distributions, 18(8), 742-753. https://doi. org/10.1111/j.1472-4642.2012.00891.x

Ding, Y., Qian, S., Wu, X., Zhao, L., Lin, D., Zhang, J., \& Yang, Y., 2019, 'Homogenization of China's urban aquatic macrophyte communities: A meta-analytic study', Ecological Indicators, 106, https://doi.org/10.1016/j.ecolind.2019.105506

Doherty, J.M., \& Zedler, J.B., 2014, 'Dominant graminoids support restoration of productivity but not diversity in urban wetlands', Ecological Engineering, 65, 101-111. https://doi.org/10.1016/j.ecoleng.2013.07.056

Dolan, R.W., Moore, M.E., \& Stephens, J.D., 2011, 'Documenting effects of urbanization on flora using herbarium records', Journal of Ecology, 99(4), 1055-1062. https://doi. org/10.1111/j.1365-2745.2011.01820.x

Ehrenfeld, J.G., 2000, 'Evaluating wetlands within an urban context', Urban Ecosystems, 4(1), 69-85. https://doi. org/10.1023/A:1009543920370

ESRI, 2010, ArcGIS, version 10.0. Redlands, CA: Environmental Systems Research Institude. Retrieved from http:// www.esri.com

Everard, M., 1997, 'Development of a British wetland strategy', Aquatic Conservation: Marine and Freshwater Ecosystems, 7(3), 223-238. https://doi.org/10.1002/(SICI)10990755(199709)7:3<223::AID-AQC239>3.0.CO;2-O

Govender-Ragubeer, Y., Meeuwis, J., \& McKay, T.M., 2014, 'A series of unfortunate events: how the battle to save an urban wetland was both won and lost', TD: The Journal for Transdisciplinary Research in Southern Africa, 10(1), 149168. https://hdl.handle.net/10520/EJC154541

Hettiarachchi, M., Morrison, T.H., \& McAlpine, C., 2015, 'Forty-three years of Ramsar and urban wetlands', Global Environmental Change, 32, 57-66. https://doi.org/10.1016/j. gloenvcha.2015.02.009

Hoeksema, R.J., 2007, 'Three stages in the history of land reclamation in the Netherlands', Irrigation and Drainage, 56(S1), S113-S126. https://doi.org/10.1002/ird.340

JB Marks Local Municipality, 2018, '2017-2018 Annual Report'. Retrieved from: http://www.jbmarks.co.za/sites/default/files/2019-06\%20documents/2017-2018\%20Annual\%20Report.pdf

Jia, H., Ma, H., \& Wei, M., 2011, 'Urban wetland planning: A case study in the Beijing central region', Ecological Complexity, 8(2), 213-221. https://doi.org/10.1016/j.ecocom.2011.03.002

Kallimanis, A.S., Mazaris, A.D., Tzanopoulos, J., Halley, J.M., Pantis, J.D., \& Sgardelis, S.P., 2008, 'How does habitat diversity affect the species-area relationship', Global Ecology and Biogeography, 17, 532-538. https://doi.org/10.1111/ j.1466-8238.2008.00393.x

Koekemoer, L., Janse van Vuuren, S., \& Levanets, A., 2021, 'The influence of land use impacted tributaries on water quality and phytoplankton in the Mooi River, North West Province, South Africa', Bothalia, 51(1): 23-44 (hardcopy); 1-22 (online) [this issue].

Kruger, D.J.D., Hamer, A.J., \& Du Preez, L.H., 2015, 'Urbanization affects frog communities at multiple scales in a rapidly developing African city', Urban Ecosystems, 18(4), 1333-1352. https://doi.org/10.1007/s11252-015-0443-y 
Lannas, K.S., \& Turpie, J.K., 2009, 'Valuing the provisioning services of wetlands: contrasting a rural wetland in Lesotho with a peri-urban wetland in South Africa', Ecology and Society, 14(2), 18. http://www.ecologyandsociety.org/vol14/ iss2/art18/

Louw, W.J., 1951, 'An ecological account of the vegetation of the Potchefstroom area', Memoirs of the Botanical Survey of South Africa, No. 24.

Manuel, P.M., 2003, 'Cultural perceptions of small urban wetlands: cases from the Halifax Regional Municipality, Nova Scotia, Canada', Wetlands, 23(4), 921-940. https://doi.org/ 10.1672/0277-5212(2003)023[0921:CPOSUW]2.0.CO;2

McGarigal, K., \& Marks, B.J., 1995, 'FRAGSTATS: spatial pattern analysis program for quantifying landscape structure. Gen. Tech. Rep. PNW-GTR-351', Pacific Northwest Research Station, Portland: U.S. Department of Agriculture, Forest Service.

McInnes, R.J., \& Everard, M., 2017, 'Rapid Assessment of Wetland Ecosystem Services (RAWES): An example from Colombo, Sri Lanka', Ecosystem Services, 25, 89-105. https://doi.org/10.1016/j.ecoser.2017.03.024

Miller, S.J., \& Wardrop, D.H., 2006, 'Adapting the floristic quality assessment index to indicate anthropogenic disturbance in central Pennsylvania wetlands', Ecological Indicators, 6(2), 313-326. https://doi.org/10.1016/j. ecolind.2005.03.012

Mucina, L., Hoare, D.B., Lötter, M.C., du Preez, P.J., Rutherford, M.C., Scott-Shaw, C.R., Bredenkamp, G.J., Powrie, L.W., Scott, L., Camp, K.G.T., Cilliers, S.S., Bezuidenhout, H., Mostert, T.H., Siebert, S.J., Winter, P.J.D., Burrows, J.E., Dobson, L., Ward, R.A., Stalmans, M., Oliver, E.G.H., Siebert, F., Schmidt, E., Kobisi, K., \& Kose, L., 2006, 'Grassland Biome' in L. Mucina \& M.C. Rutherford (Eds.) The Vegetation of South Africa, Lesotho and Swaziland. Strelitzia 19. Pretoria: South African National Biodiversity Institute, pp. 349-436.

Panuccio, M., Foschi, F., Audinet, J.-P., Calò, C.M., \& Bologna, M.A., 2017, 'Urban wetlands: wastelands or hotspots for conservation? Two case studies from Rome, Italy', Avocetta, 41, 13-18 https://doi.org/10.30456/AVO.2018103

Parker, K.A., Springall, B.T., Garshong, R.A., Malachi, A.N., Dorn, L.E., Costa-Terryll, A., Mathis, R.A., Lewis, A.N., MacCheyne, C.L., Davis, T.T., Rice, A.D., Varh, N.Y., Li, H., Schug, M.D., \& Kalcounis-Rueppell, M.C., 2018, 'Rapid Increases in Bat Activity and Diversity after Wetland Construction in an Urban Ecosystem', Wetlands, 39(4), 717727. https://doi.org/10.1007/s13157-018-1115-5

Pedersen, E., Weisner, S.E.B., \& Johansson, M., 2019, 'Wetland areas' direct contributions to residents' well-being entitle them to high cultural ecosystem values', Science of the Total Environment, 646, 1315-1326. https://doi. org/10.1016/j.scitotenv.2018.07.236

Perron, M.A.C., \& Pick, F.R., 2020, 'Stormwater ponds as habitat for Odonata in urban areas: the importance of obligate wetland plant species', Biodiversity and Conservation, 29(3), 913-931. https://doi.org/10.1007/s10531019-01917-2

Pretorius, C., Du Toit, M., \& Cilliers, S., 2013, 'Effect of land-cover change on the vegetation types and ecosystem services of the Tlokwe Municipal Area, North West Province', South African Journal of Botany(86), 165-166. https://doi.org/10.1016/j.sajb.2013.02.103
Purseglove, J.J., 1989, 'Taming the Flood: a history and natural history of rivers and wetlands', Oxford: Oxford University Press.

Ramírez, F., \& Santana, J.C., 2019, 'Key lessons learned by teaching ecotourism to undergraduate students in Bogotá's urban wetlands', Applied Environmental Education \& Communication, 18(3), 234-251. https://doi.org/10.108 0/1533015X.2018.1454359

Ramsar Convention Secretariat, 2013, 'The Ramsar Convention Manual: a guide to the Convention on Wetlands (Ramsar, Iran, 1971)', (6th ed.), retrieved from https:// www.ramsar.org/sites/default/files/documents/library/manual6-2013-e.pdf

Retief, E., \& Herman, P.P.J., 1997, Plants of the northern provinces of South Africa: keys and diagnostic characters, Strelitzia 6, National Biodiversity Institute, Pretoria.

Roberts, D., 1993, 'The vegetation ecology of municipal Durban, Natal: floristic classification', Bothalia, 23(2), 271-326. https://doi.org/10.4102/abc.v23i2.813

Ruto, W., Kinyamario, J., Ng'etich, N., Akunda, E., \& Mworia, J., 2012, 'Plant species diversity and composition of two wetlands in the Nairobi National Park, Kenya', Journal of Wetlands Ecology, 6, 7-15. https://doi.org/10.3126/jowe. v6i0.5909

Semlitsch, R.D., \& Bodie, J.R., 1998, 'Are small, isolated wetlands expendable?', Conservation Biology, 12(5), 11291133. https://doi.org/10.1046/j.1523-1739.1998.98166.x

Sieben, E.J.J., Collins, N.B., Corry, F.T.J., Kotze, D.C., Job, N., Muasya, A.M., Venter, C.E., Mtshali, H., Zondo, S.A., Janks, M., \& Pretorius, L., 2016, 'The vegetation of grass lawn wetlands of floodplains and pans in semi-arid regions of South Africa: Description, classification and explanatory environmental factors', South African Journal of Botany, 104, 215-224. https://doi.org/10.1016/j.sajb.2015.11.003

Sieben, E.J.J., Collins, N.B., Kotze, D.C., Mofutsanyana, S.S., \& Janks, M., 2017, 'Temperate grassy wetlands of South Africa: Description, classification and explanatory environmental factors', South African Journal of Botany, 113, 68-76. https://doi.org/10.1016/j.sajb.2017.07.009

Sieben, E.J.J., Mtshali, H., \& Janks, M., 2014, 'National Wetland Vegetation Database: Classification and analysis of wetland vegetation types for conservation planning and monitoring. WRC Report No. 1980/1/14': W. R. Commission.

Skowno, A.L., Poole, C.J., Raimondo, D.C., Sink, K.J., Van Deventer, H., Van Niekerk, L., Harris, L.R., Smith-Adao, L.B., Tolley, K.A., Zengeya, T.A., Foden, W.B., Midgley, G.F., \& Driver, A., 2019, 'National Biodiversity Assessment 2018: The status of South Africa's ecosystems and biodiversity. Synthesis Report', South African National Biodiversity Institute \& Departement of Environment, Forestry and Fisheries, http://hdl.handle.net/20.500.12143/6362

Soomers, H., Karssenberg, D., Soons, M.B., Verweij, P.A., Verhoeven, J.T.A., \& Wassen, M.J., 2013, 'Wind and water dispersal of wetland plants across fragmented landscapes', Ecosystems, 16(3), 434-451. https://doi.org/10.1007/ s10021-012-9619-y

South Africa, 1998, 'National Water Act 36 of 1998', Pretoria: Government Printer

Tiner, R.W. ,1999, 'Wetland Indicators: a guide to wetland identification, delineation, classification and mapping', USA: Washington D.C.: Lewis Publishers. 
Tiner, R.W., 2006, 'Lists of potential hydrophytes for the united states: a regional review and their use in wetland identification', Wetlands, 26(2), 624-634. https://doi.org/10.1 672/0277-5212(2006)26[624:LOPHFT]2.0.CO;2

Van der Walt, L., Cilliers, S.S., Du Toit, M.J., \& Kellner, K., 2014, 'Conservation of fragmented grasslands as part of the urban green infrastructure: how important are species diversity, functional diversity and landscape functionality?', Urban Ecosystems, 18, 87-113. https://doi.org/10.1007/ s11252-014-0393-9

Van Deventer, H., van Niekerk, L., Adams, J., Dinala, M.K., Gangat, R., Lamberth, S.J., Lötter, M., Mbona, N., Mackay, F., Nel, J.L., Ramjukadh, C.-L., Skowno, A., \& Weerts, S.P., 2020, 'National Wetland Map 5: An improved spatial extent and representation of inland aquatic and estua- rine ecosystems in South Africa', Water SA, 46(1), 66-79, https://doi.org/10.17159/wsa/2020.v46.i1.7887

Van Ginkel, C., Glen, R., Gordon-Gray, K., Cilliers, C., Muasya, M., \& Van Deventer, P., 2011, 'Easy identification of some South African wetland plants (grasses, restios, sedges, rushes, bulrushes, eriocaulons and yellow-eyed grasses)', Water Research Commission, Gezina,(WRC Report No. TT 479/10).

Wondie, A., 2018, 'Ecological conditions and ecosystem services of wetlands in the Lake Tana Area, Ethiopia', Ecohydrology \& Hydrobiology, 18(2), 231-244, https://doi. org/10.1016/j.ecohyd.2018.02.002

Working for Wetlands, 2019, Introduction and background [online], available at: www.environment.gov.za/projectsprogrammes/workingfowetlands (Accessed: 1 October 2019) 


\section{Supplementary material}

\section{Correlation matrix and species lists}

Table S1. Correlation matrix of the urbanisation measures to determine their association with each other

\begin{tabular}{lllll}
\hline & Percent urbanisation & Edge density & Percent vegetation & Density of dwellings \\
\hline Percent urbanisation & 1 & & & \\
Edge density & 0.903076 & 1 & 1 & \\
\hline Percent vegetation & -0.97182 & -0.93049 & -0.96461 & 1 \\
\hline Density of dwellings & 0.993281 & 0.891734 & \\
\hline
\end{tabular}

Table S2. List of all the species recorded in this study. Indicated are the respective number of transects in which the species were found and their representative percentage occurrence in urban and rural sites

\begin{tabular}{|c|c|c|c|c|}
\hline Species name & $\begin{array}{l}\text { No. of urban } \\
\text { transects }\end{array}$ & $\begin{array}{l}\text { urban \% } \\
\text { occurrence }\end{array}$ & $\begin{array}{l}\text { No. of rural } \\
\text { transects }\end{array}$ & rural $\%$ occurrence \\
\hline Agrostis continuata & 2 & 2.9 & 0 & 0.0 \\
\hline Albuca setosa & 0 & 0.0 & 2 & 3.2 \\
\hline Alternanthera sessilis & 0 & 0.0 & 27 & 43.5 \\
\hline Ambrosia psilostachya & 11 & 16.2 & 0 & 0.0 \\
\hline Ammi majus & 3 & 4.4 & 0 & 0.0 \\
\hline Andropogon appendiculatus & 0 & 0.0 & 4 & 6.5 \\
\hline Anthospermum herbaceum & 0 & 0.0 & 5 & 8.1 \\
\hline Asparagus laricinus & 0 & 0.0 & 1 & 1.6 \\
\hline Aster squamatus & 2 & 2.9 & 22 & 35.5 \\
\hline Berkheya setifera & 1 & 1.5 & 2 & 3.2 \\
\hline Berula erecta & 27 & 39.7 & 6 & 9.7 \\
\hline Bidens pilosa & 0 & 0.0 & 1 & 1.6 \\
\hline Bidens bipinatta & 0 & 0.0 & 1 & 1.6 \\
\hline Brachiaria eruciformis & 3 & 4.4 & 49 & 79.0 \\
\hline Carex acutiformis & 3 & 4.4 & 0 & 0.0 \\
\hline Carex glomerabilis & 58 & 85.3 & 6 & 9.7 \\
\hline Cichorium intybus & 3 & 4.4 & 0 & 0.0 \\
\hline Cirsium vulgare & 4 & 5.9 & 6 & 9.7 \\
\hline Chenopodium album & 0 & 0.0 & 1 & 1.6 \\
\hline Conyza bonariensis & 0 & 0.0 & 6 & 9.7 \\
\hline Cotula australis & 0 & 0.0 & 1 & 1.6 \\
\hline Crinum bulbispermum & 7 & 10.3 & 13 & 21.0 \\
\hline Cynodon dactylon & 36 & 52.9 & 12 & 19.4 \\
\hline
\end{tabular}


Table S2. List of all the species recorded in this study. Indicated are the respective number of transects in which the species were found and their representative percentage occurrence in urban and rural sites (continued)

\begin{tabular}{|c|c|c|c|c|}
\hline Species name & $\begin{array}{l}\text { No. of urban } \\
\text { transects }\end{array}$ & $\begin{array}{l}\text { urban \% } \\
\text { occurrence }\end{array}$ & $\begin{array}{l}\text { No. of rural } \\
\text { transects }\end{array}$ & rural $\%$ occurrence \\
\hline Cynodon transvaalensis & 1 & 1.5 & 14 & 22.6 \\
\hline Cyperus congestus & 13 & 19.1 & 0 & 0.0 \\
\hline Cyperus eragrostis & 0 & 0.0 & 3 & 4.8 \\
\hline Cyperus esculentus & 0 & 0.0 & 2 & 3.2 \\
\hline Cyperus fastigiatus & 18 & 26.5 & 36 & 58.1 \\
\hline Cyperus laevigatus & 43 & 63.2 & 29 & 46.8 \\
\hline Cyperus longus & 67 & 98.5 & 52 & 83.9 \\
\hline Cyperus marginatus & 1 & 1.5 & 0 & 0.0 \\
\hline Echinochloa colona & 0 & 0.0 & 8 & 12.9 \\
\hline Echinochloa holubii & 7 & 10.3 & 42 & 67.7 \\
\hline Echinochloa pyramidalis & 3 & 4.4 & 4 & 6.5 \\
\hline Eleocharis dregeana & 17 & 25.0 & 9 & 14.5 \\
\hline Eragrostis curvula & 0 & 0.0 & 4 & 6.5 \\
\hline Eragrostis heteromera & 7 & 10.3 & 15 & 24.2 \\
\hline Eragrostis micrantha & 0 & 0.0 & 2 & 3.2 \\
\hline Eragrostis plana & 0 & 0.0 & 3 & 4.8 \\
\hline Euphorbia helioscopia & 26 & 38.2 & 0 & 0.0 \\
\hline Falckia oblonga & 32 & 47.1 & 44 & 71.0 \\
\hline Festuca caprina & 4 & 5.9 & 3 & 4.8 \\
\hline Fuirena pachyrrhiza & 0 & 0.0 & 2 & 3.2 \\
\hline Fuirena pubescens & 0 & 0.0 & 1 & 1.6 \\
\hline Gleditsia triacanthos & 6 & 8.8 & 0 & 0.0 \\
\hline Gomphrena celosiodes & 1 & 1.5 & 0 & 0.0 \\
\hline Haplocarpha lyrata & 0 & 0.0 & 1 & 1.6 \\
\hline Heliochrysum krausii & 1 & 1.5 & 0 & 0.0 \\
\hline Hemarthria altissima & 54 & 79.4 & 45 & 72.6 \\
\hline Hibuscus trionum & 3 & 4.4 & 8 & 12.9 \\
\hline Hydrocotyla verticillata & 1 & 1.5 & 0 & 0.0 \\
\hline Juncus punctorius & 3 & 4.4 & 1 & 1.6 \\
\hline Juncus rigidus & 2 & 2.9 & 1 & 1.6 \\
\hline Kniphofia ensifolia & 6 & 8.8 & 3 & 4.8 \\
\hline Lactuca capensis & 23 & 33.8 & 0 & 0.0 \\
\hline Lactuca inermis & 16 & 23.5 & 0 & 0.0 \\
\hline Leersia hexandra & 61 & 89.7 & 43 & 69.4 \\
\hline Lobelia thermalis & 2 & 2.9 & 0 & 0.0 \\
\hline
\end{tabular}


Table S2. List of all the species recorded in this study. Indicated are the respective number of transects in which the species were found and their representative percentage occurrence in urban and rural sites (continued)

\begin{tabular}{|c|c|c|c|c|}
\hline Species name & $\begin{array}{l}\text { No. of urban } \\
\text { transects }\end{array}$ & $\begin{array}{l}\text { urban \% } \\
\text { occurrence }\end{array}$ & $\begin{array}{l}\text { No. of rural } \\
\text { transects }\end{array}$ & rural $\%$ occurrence \\
\hline Marsilea capensis & 37 & 54.4 & 30 & 48.4 \\
\hline Medicago sativa & 0 & 0.0 & 1 & 1.6 \\
\hline Melilotus alba & 10 & 14.7 & 1 & 1.6 \\
\hline Mentha aquatica & 5 & 7.4 & 0 & 0.0 \\
\hline Modiola caroliana & 2 & 2.9 & 0 & 0.0 \\
\hline Moraea thomsonii & 0 & 0.0 & 2 & 3.2 \\
\hline Oenothera rosea & 12 & 17.6 & 9 & 14.5 \\
\hline Oxalis corniculata & 0 & 0.0 & 1 & 1.6 \\
\hline Panicum coloratum & 0 & 0.0 & 1 & 1.6 \\
\hline Paspalum dilatatum & 62 & 91.2 & 16 & 25.8 \\
\hline Paspalum distichum & 36 & 52.9 & 36 & 58.1 \\
\hline Pennisetum cladestinum & 0 & 0.0 & 3 & 4.8 \\
\hline Persicaria decipiens & 12 & 17.6 & 19 & 30.6 \\
\hline Persicaria lapathifolia & 2 & 2.9 & 23 & 37.1 \\
\hline Persicaria senegalensis & 0 & 0.0 & 2 & 3.2 \\
\hline Phragmites australis & 26 & 38.2 & 4 & 6.5 \\
\hline Plantago lanceolata & 8 & 11.8 & 9 & 14.5 \\
\hline Plantago major & 5 & 7.4 & 5 & 8.1 \\
\hline Pycreus macranthus & 18 & 26.5 & 12 & 19.4 \\
\hline Pycreus macrostachyos & 9 & 13.2 & 5 & 8.1 \\
\hline Pycreus nitidus & 2 & 2.9 & 0 & 0.0 \\
\hline Rumex crispus & 43 & 63.2 & 43 & 69.4 \\
\hline Rumex lanceolatus & 1 & 1.5 & 4 & 6.5 \\
\hline Salix babylonica & 1 & 1.5 & 0 & 0.0 \\
\hline Schoenoplectus brachyceras & 18 & 26.5 & 4 & 6.5 \\
\hline Schoenoplectus corymbosus & 1 & 1.5 & 1 & 1.6 \\
\hline Sesbania bispinosa & 3 & 4.4 & 3 & 4.8 \\
\hline Sesbania transvaalensis & 0 & 0.0 & 11 & 17.7 \\
\hline Setaria incrassata & 0 & 0.0 & 5 & 8.1 \\
\hline Setaria pallide-fusca & 2 & 2.9 & 26 & 41.9 \\
\hline Sisymbrium thellungii & 9 & 13.2 & 0 & 0.0 \\
\hline Solanum retroflexum & 0 & 0.0 & 1 & 1.6 \\
\hline Sonchus oleraceus & 1 & 1.5 & 4 & 6.5 \\
\hline Sonchus wilmsii & 0 & 0.0 & 1 & 1.6 \\
\hline Sporobolus fimbriatus & 4 & 5.9 & 0 & 0.0 \\
\hline
\end{tabular}


Table S2. List of all the species recorded in this study. Indicated are the respective number of transects in which the species were found and their representative percentage occurrence in urban and rural sites (continued)

\begin{tabular}{|c|c|c|c|c|}
\hline Species name & $\begin{array}{l}\text { No. of urban } \\
\text { transects }\end{array}$ & $\begin{array}{l}\text { urban \% } \\
\text { occurrence }\end{array}$ & $\begin{array}{l}\text { No. of rural } \\
\text { transects }\end{array}$ & rural $\%$ occurrence \\
\hline Taraxacum officinale & 0 & 0.0 & 1 & 1.6 \\
\hline Typha capensis & 29 & 42.6 & 4 & 6.5 \\
\hline Trifolium africanum & 0 & 0.0 & 1 & 1.6 \\
\hline Trifolium repens & 16 & 23.5 & 0 & 0.0 \\
\hline Verbena brasiliensis & 4 & 5.9 & 0 & 0.0 \\
\hline Verbena bonariensis & 1 & 1.5 & 2 & 3.2 \\
\hline Verbena officinalis & 0 & 0.0 & 36 & 58.1 \\
\hline Veronica anagalis-aquatica & 35 & 51.5 & 0 & 0.0 \\
\hline Xanthium strumarium & 17 & 25.0 & 12 & 19.4 \\
\hline
\end{tabular}

Table S3. List of the alien invasive species found in the wetland sites that are listed in the Conservation of Agricultural Resources Act, 1983 (Act No. 43 of 1983) (CARA) and the National Environmental Management: Biodiversity Act (Act No. 10 of 2004) (NEM:BA) and their presence and cover abundance in the urban and rural transects respectively

\begin{tabular}{|c|c|c|c|c|c|c|}
\hline Species name & CARA & NEM:BA & 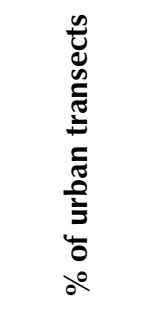 & 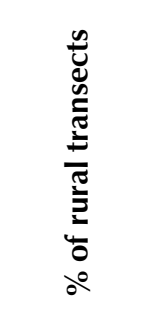 & 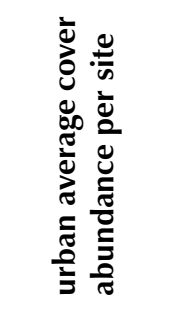 & 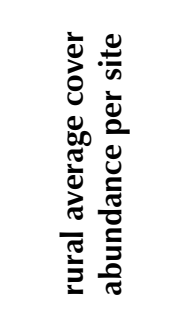 \\
\hline Cirsium vulgare & 1 & $1 \mathrm{~b}$ & 5.882353 & 9.677419 & 0.027862 & 0.05027778 \\
\hline Gleditsia triacanthos & 2 & $\begin{array}{l}\text { 1b. Sterile cultivars or } \\
\text { hybrids not listed }\end{array}$ & 8.823529 & 0 & 0.0078947 & 0 \\
\hline Pennisetum clandestinum & $\begin{array}{l}\text { Not } \\
\text { listed }\end{array}$ & $\begin{array}{l}\mathbf{1 b} \text { in Protected Areas } \\
\text { and wetlands in which it } \\
\text { does not already occur. } \\
\text { Not listed elsewhere. }\end{array}$ & 0 & 4.83871 & 0 & 0.01130268 \\
\hline Salix babylonica & 2 & Not listed & 1.470588 & 0 & 0.0921053 & 0 \\
\hline Verbena bonariensis & $\begin{array}{l}\text { Not } \\
\text { listed }\end{array}$ & $1 \mathrm{~b}$ & 5.882353 & 0 & 0.0058366 & 0.00277778 \\
\hline Verbena brasiliensis & $\begin{array}{l}\text { Not } \\
\text { listed }\end{array}$ & $1 b$ & 0 & 58.06452 & 0.0107004 & 0 \\
\hline Xanthium strumarium & 1 & $1 b$ & 25 & 19.35484 & 0.0841977 & 0.06470085 \\
\hline
\end{tabular}




\section{Urbanisation gradient}

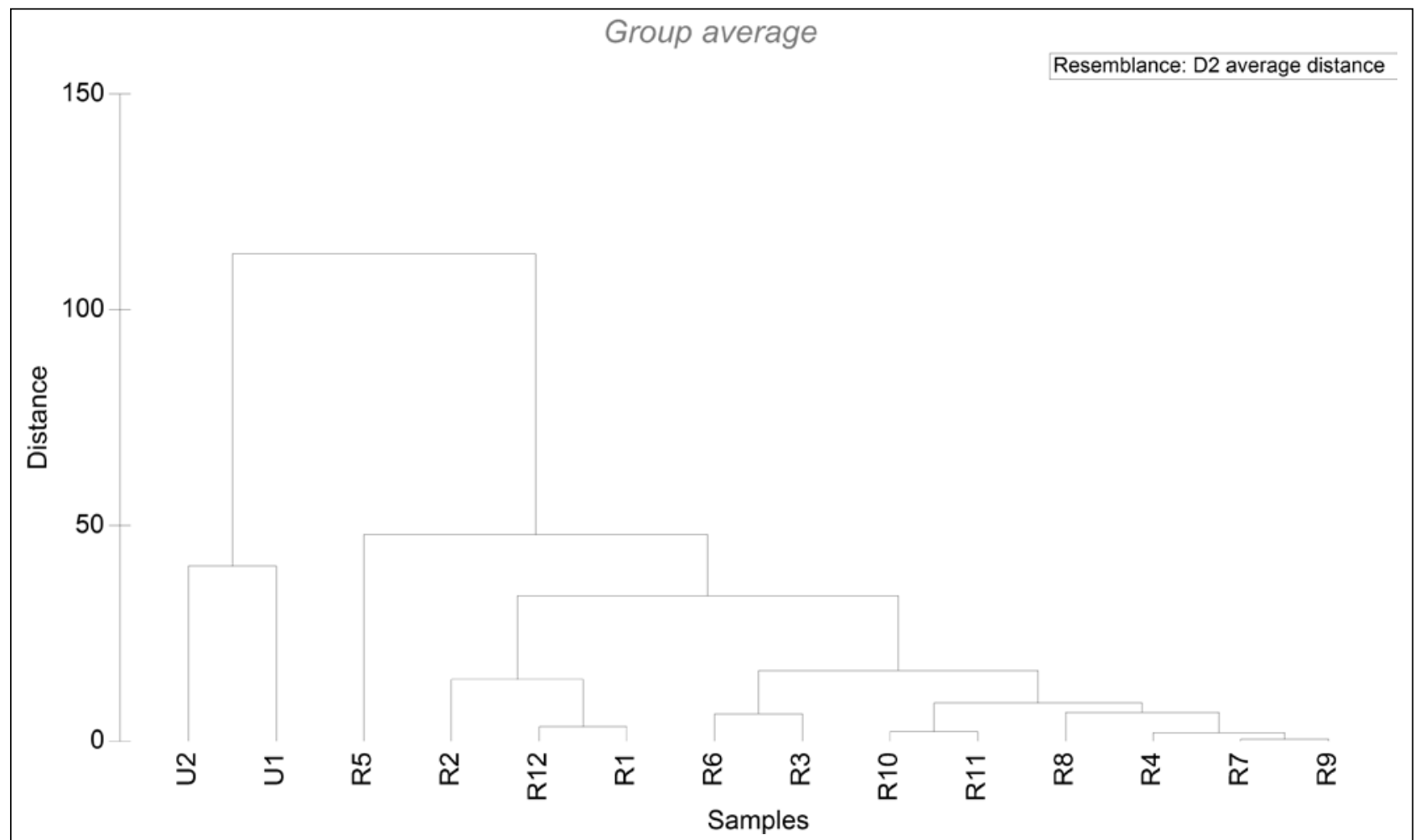

Figure S1. Cluster analysis results based on the urbanisation measures indicating clear grouping between the urban sites 1 and 2 and the rural sites.

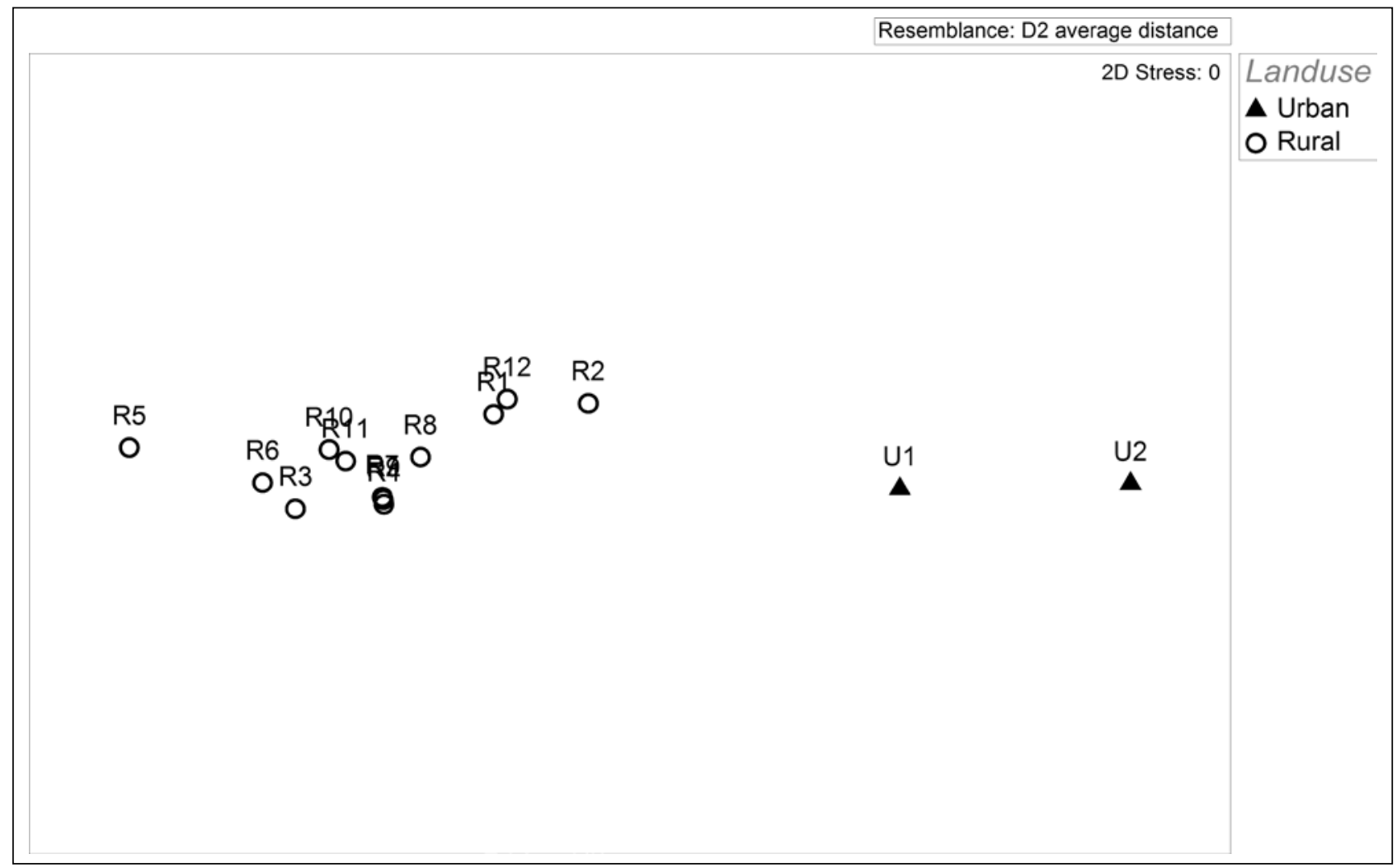

Figure S2. MDS ordination indicating the clear separation of the two land use groups based on the urbanisation measures. 